\title{
Effect of Group Composition and Formalization on Financial Performance of Investment Groups in Kenya
}

\author{
Rose Kirui ${ }^{1, *}$, Samuel Onyuma ${ }^{2}$ \\ ${ }^{1}$ Faculty of Commerce, Egerton University, Nakuru, Kenya \\ ${ }^{2}$ School of Business, Laikipia University, Nyahururu, Kenya \\ Email address: \\ roseckirui@gmail.com (R. Kirui), onyumadoc@gmail.com (S. Onyuma) \\ ${ }^{*}$ Corresponding author
}

\section{To cite this article:}

Rose Kirui, Samuel Onyuma. Effect of Group Composition and Formalization on Financial Performance of Investment Groups in Kenya. International Journal of Economics, Finance and Management Sciences. Vol. 7, No. 2, 2019, pp. 65-73. doi: 10.11648/j.ijefm.20190702.13

Received: April 10, 2019; Accepted: May 20, 2019; Published: June 12, 2019

\begin{abstract}
Investment groups are important for pooling of financial resources and lowering of investment risk. The issues, which affect their rates of return on investment, is however not fully known. The objective of the study was to analyze the effect of the group composition and group formalization on the financial performance of investment groups in Nakuru Town Kenya. Descriptive survey design was used and stratified sampling technique was used to select a sample of 130 investment group members as well as investment groups. Data was analyzed using inferential statistics. The results shows that group composition and group formalization influence financial performance of investment groups positively and significantly. The study recommend that policies should be crafted that encourage gender mainstreaming in investment groups and registration of investment groups with members from different ethnic and occupational backgrounds. Training programs and member education on business skills and proper management practices are paramount in improving the financial performance of these groups.
\end{abstract}

Keywords: Group Composition, Group Formalization, Financial Performance, Group Homogeneity

\section{Introduction}

In the last decade, there has been a growing attention on investments as a tool of economic development across the world. Investments means the commitment of funds, which have been saved from current consumption, to purchase financial instruments or other assets with the hope that some benefits will accrue in future in form of interest, income, or appreciation of capital [1]. Typical, working people across the world are joining forces to form investment groups, which are voluntary associations of a few people who pool money to save in order to do joint investments. There is no ideal number of participants for a successful investment group. It should have a manageable size to facilitate constructive discussions regarding investments and enough members to generate sufficient funds through regular contributions for the main purpose of investing [2].

The investment groups have either been transformed into saving and investment groups from self-help groups or were formed for that purpose right from inception [3]. They are not a get-rich-quick scheme, but members are individuals who are focused on the long term investments. Since they are financial partnerships, some investment groups may incorporate to protect members' assets and to facilitate compliance with the accounting rules observed by law [4]. An investment group represents an archetypal example of an organization in which interactional processes can be observed [5]. Investment groups can be composed of people of different business experiences, gender, occupational and business training backgrounds.

Based on a European model going back several generations, the first U.S. investment group was founded in Texas in 1898 and have existed in the United States for at least a century. though they did not become extremely popular until the 1990s when they constituted the major vehicle of finance that has attracted so much attention from the media and policy makers [4]. During the 1990s the popularization of investing and investment groups in the United States was facilitated by several organizational and 
technical developments most notably being that of discount brokerage firms and the world wide web which lowered transaction costs and made it possible to invest efficiently as a group [4].

The informal savings groups are Self- help groups divided into three categories, which are financial, welfare and investment groups. The first category, which is generally, the most common groups, is financial Self-help groups. It could be defined in the name of Rotating savings and credit associations (ROSCAs), or Accumulating savings and credit associations (ASCAs). These informal associations come together for savings (ROSCAs) and lend out at certain percentage of interest (ASCAs) in a regular basis. The second category is welfare groups are support groups, in which members provide each other with various types of help, usually nonprofessional and nonmaterial, for a particular common problem [6].

The third category is investment groups, which are vehicles for investments usually in land, the stock market, or in new businesses ventures. The purpose of forming investment groups according to is to buy assets, to exchange business ideas, to network and to mobilize funds for investments [7]. Currently, local investment groups in Kenya hold a total of about 35 billion Kenyan shillings, equivalent to US\$469 million [3]. One of the major investment groups in Kenya is Transcentury Limited, a part owner of the KenyaUganda Rift Valley Railways. This together with Centum Investment Limited make Kenya a home to two of the regional leading companies that have origins of investment [8].

Investment groups with members who are experienced in the field of business have a high chance of success. The greater understanding of the ways in which people learn to work in entrepreneurial ways is needed if significant advance in entrepreneurial activity is to take place since learning is critical to entrepreneurial effectiveness [9]. Learning is an experiential process through which concepts are derived from and modified by experience. The experience of the entrepreneur is one factor that explains the difference in external financing levels available to MSEs [10]. Group members however, are usually amateur investors who connect with other investors to learn about investing techniques and to get advice and tips on investments [11].

Men and women have different approaches to investing and the combination of this in a decision making group can produce a synergistic diversity of views that is well suited to a dynamic external environment [4]. Men are more overconfident than women, as the latter are more risk averse $[12,13]$. Younger and unmarried women are usually risk takers while older and married ones avoid taking risk According to [14]. One of Harrington's most intriguing findings is that groups of men and women together are more profitable than single-sex groups [4].

Investment groups generate capital from the monthly contributions from the members. Members can agree to have a target figure to kick start the investments where they are all required to put in a certain amount [15]. Sources of financing therefore can include equity which can be raised either internally or externally. Equity has a minimum cash outflow unlike debts in which interests are paid periodically [16]. Other sources of funds available to investment groups include debts. short-term debt advantages include zero interest rate in some short-term debt cases such as in the case of trade credit and lower costs of flotation than those of longterm loans or equity. Interests are also allowable expenses in tax computations [17]. Another source of finance is from government initiatives like women and youth funds [15].

Investment groups play a critical role in Kenya's capital formation, which is a key ingredient in the realization of Vision 2030. Investment groups are the unsung heroes of the investment world. Investment groups are expected to contribute greatly in mobilizing local capital and to command more ownership in the local economy, leading to economic development, independence from donors and closing the income generation gap. Investment decision-making process is considered to be critical for every investor and it is a cognitive process which results in the selection of a course of action from several alternatives. Investors need to make wise decisions on whom to join up with to form an investment group and whether or not to formalize their group. Investment groups can conduct economic activity in many forms and must decide whether to organize a close or publicly held corporation, a general or limited partnership, or just a self-help group. The assessment of group financial performance in this context becomes highly essential. The objective of the study was to determine the effect of group composition and group formalization on the financial performance of investment groups in Nakuru town.

\section{Literature Review}

Having a group of interested dedicated people is not a guarantee that an investment group will have a very good financial performance. An investment group needs a variety of people who will bring in diverse individual skills and experiences to the group. Some of the skills and experiences have been acquired due to having invested in different industries, being in different occupations or having undergone some business training over time. Overconfident investors tend to overestimate their abilities or the precision of their knowledge. Consequently, they usually hold riskier portfolios and trade more than maximizing expected utility would suggest [12]. The investment experience and age have a significant impact on the degree of overconfidence that goes surprisingly in opposite direction [18]. Mostly, interest in risky investments will be expressed by participants with no investment experience, given the opportunity to choose among a mix of investments including risk-based fund option. The participants that are willing to take higher risks to give themselves the chance of making higher returns tend to be young [19]. Men are risk takers who trade more than women do. Men have been found to be more overconfident than women, trade more but perform worse than women [12].

Business training is an important factor influencing 
entrepreneurial performance and income because it increases education level in general. Training affects both female and male entrepreneurship in a positive manner, although what is more is the fact that the influence of business training is greater on female entrepreneurial activity than on male entrepreneurship [20]. The personal as well as environmental factors influence investors in formulating their perceptions on investment avenues [21]. In decisions relating to investment, investors have certain weaknesses like cognitive and emotional that take a predominating role. Investors adopt some investment avenues after analyzing different factors that are influenced by their internal and external environments. Men and women have very different occupational experiences and therefore gender differences in investing may be seen as a result. The gender gap in investing experience is because of women less likely to have been offered opportunities [22].

Investors hardly act rationally in taking decisions while investing. Investors simply react on the available information possessed by them and react accordingly. Investors should as far as possible try to make fundamental, technical and financial analysis before investing in the shares. There are many considerations while investing such as tax planning, future needs, safety of investments and recurring income. Investors who possess financial information therefore make better investments decisions [23].

Harrington examined decision-making processes in investment groups, employing the conceptual and analytical tools of economic sociology. As formal associations for consultation and discussion of financial decisions, Harrington found that investment groups provide an interesting arena for scholarly observation in which decision-making processes in finance are made transparent. She analyzed how the composition of groups in investment groups, on the one hand, and the way in which information is used in-group processes, on the other hand, impact on investment performance. Harrington's findings on the diversity premium suggest interesting implications. Group heterogeneity impacts on investment performance in positive ways, the more decision-making processes in the group can withstand the numerous forces pushing members toward conformity of opinion [4]. Using the principles of behavioral finance, the psychological concept of individual attachment style, mainly the urban investors to different available investment avenues and their investment preference process. There is significant role of income and occupation in investment avenue selection by the investors [21].

Education is one of the factors that affect positively on growth of firms [24]. Investors with business knowledge have the ability to get appropriate information from the business environment that is relevant and useful for their investments [25]. Business training helps investors to cope with the latest accounting systems, information technology, management concepts and production [26]. Business training lead to some changes in business practices for women already in business, but had no impact on business profits, sales or capital stock. However, both profitability and business practices of the new entrants were increased by training, suggesting that business training may be more effective for new investment than for existing businesses [27]. Due to gender differences in education or business networks, women might be relatively uninformed about investment opportunities and they might also be untrained in basic cost-benefit analysis [28].

Those investment groups with larger proportion of members with business education and (or) vocational training, are better placed to adapt their enterprises to constantly changing business environments [24]. A field research was carried out in Tanzania, which jointly investigated the importance of a human capital intervention (business training) and a financial capital intervention (business grant). Using data from three survey rounds, a lab experiment and administrative records of the microfinance institution, they concluded that business training is essential to transform financial capital into productive investments [29].

Business training of investors always lead to improved profitability of an investment. Entrepreneurship training lead to improved business knowledge, practices and revenue [30]. Individuals can be taught to engage in certain good business practices, which can lead to increased sales. Business training enabled the entrepreneurs to better identify business opportunities, leading to changes in business practices and ultimately higher sales and profits [31]. Development of new financial products and the complexity of financial markets have led to an increased importance of improving financial literacy amongst investors. A significant relationship between financial literacy and investment decisions and women have a lower level of financial literacy than men [32].

A study by the National Center on Women and Aging showed that men have more informational diversity than women do. Women, unlike men did not read specialty financial publications such as Wall Street Journal on investors and Business, but got their business ideas from friends, relatives and general interest newspapers [33]. Men get investing ideas form financial specialty publications and internet [4]. The most important principal factors that influence investment decisions are past performance of the company stock, expected stock split, bonus, dividend policy and expected corporate earnings. Investors are enlightened on the factors that are necessary to maximize their wealth in the capital market [34]. The economic liberalization and globalization have brought a fervent environment for the common and small investors who are willing to participate in the various investment avenues available. Investments are done in various investment avenues with the expectation of capital appreciation and short and long term earnings. The investor should therefore analyse the market cautiously and then make investment decision [35].

Conflict of preference, ethnicity, and prejudice can easily lead to management difficulties in an investment group; however, an ethnic mix can also bring about a variety in abilities, experiences, cultures which may be productive and may lead to innovation and creativity [36]. Ethnic diversity is 
likely to have important cultural, economic, fiscal, and developmental benefits. In the short run however, ethnic diversity tend to reduce social solidarity and social capital. New evidence from the US suggests that in ethnically diverse neighborhoods residents of all races tend to 'hunker down'. Trust - even of one's own race - is lower, while altruism and community cooperation is rare [37].

In many developing countries, the ethnic makeup of local business communities is quite different from that of the population at large. It is not common for members of a particular ethnic group to account for an overwhelming proportion of entrepreneurs [38]. Sociologists have emphasized that African entrepreneurs prefer to do business with members of their own ethnic group [39]. They have emphasized the role that trust and reputation among individuals and communities play in creating an enabling environment for trade. There is a consensus that sharing the same ethnicity and religion are elements that favor the establishment of trust [40]. Members who share the same ethnicity as the chairperson are 20 to 25 percentage points more likely to borrow from the group or from other members; hence, ethnicity matters in gaining access to group resources, especially in the form of cheap loans [41].

Members of more homogeneous groups, both in terms of geographical proximity and of cultural affiliation, are more likely to save and to repay their loans. Cultural homogeneity is measured through a score attributed by enumerators to each respondent based on his/her language, dress and hairstyle. These findings suggest that monitoring and enforcement within groups are easier, the greater the social affinity among their members [28]. The basic idea of network effects is that information about opportunities circulates along interpersonal networks. Investors with better networks collect more accurate information, which enables them to seek out market opportunities more aggressively. Network implications of ethnicity account for the differences in firm productivity, investment and growth prospects [42]. Network effects have a strong and systematic effect on trust and information sharing [38].

Informality is pervasive amongst firms in developing countries, and simple comparisons of formal and informal firms usually reveal that formal firms are more productive and profitable. Formal firms are defined as those that are registered to pay taxes (i.e. have a tax code), a common indicator of formality in the literature [43-45]. The attributes of group formalization are organizational form, financial management, accounting and auditing, financial reporting and tax returns. The choice of organizational form for business has been of interest to investors. The law offers a menu of choices, including liability companies (LLCs) and general partnerships (GPs). Each organizational form has its own set of default rules. Prevailing theories based on unlimited liability, profit sharing, and illiquidity are insufficient and, the choice of form decision is quite complex. It depends on a variety of factors, including the behavior of other similarly situated firms that the decision makers consider competitors for prestige and clients.
Nonetheless, it is apparent that unlimited liability is generally considered burdensome, and it is the authors' prediction that, at some point in time, nearly all the firms in their sample will choose to file as limited liability partnerships [46].

Businesses planning in general involve minimization of income taxes, limitation of individual liability, and provision of flexibility and ease in operation ([47]. By taxing the income of corporate firms at a different rate than noncorporate firms, taxes can play an important role in a firm's choice of organizational form. The sensitivity of the organizational form decision to tax rates provides a key indicator of the distortion created by the corporate income tax. A significant impact of the relative taxation of corporate to personal income on the share of real economic activity that is done by corporations. The double taxation issue bears quite heavily on the choice of organizational form [48].

Financial management is one of the key aspects of the well-being and survival of a business. There is a clear evidence that three important core financial management components were used by the MSEs namely financial planning and control, financial accounting, and working capital management. Other financial management components namely, financial analysis, management accounting, and capital budgeting were used by a smaller percentage of these enterprises [49]. Large corporations have reaped the benefits of following best practice in financial and management accounting to become more competitive. Such best practice can be used as a benchmark to improve performance in micro and small enterprises but very few studies have been undertaken to determine this. Like large firms, MSEs also require adequate and sophisticated management accounting techniques and systems to better manage scarce resources hence better financial performance [50].

A business borrowing from a bank to finance the working capital will be subject to increased financial requirements that come with a cost from the bank's interest charges. Cash flow problems of many small businesses are made worse by poor financial management and in particular lack of planning cash requirements. Overtrading in the MSE business would result to working capital constraints and affect business profitability which arises from increased working capital requirements [51]. MSEs have limited access to long term capital markets and rely heavily on owner financing, trade credit and short term bank loans to finance their needed investment in cash, accounts receivables and inventory [52]. Managing cash flows and cash conversion cycle is a critical component of overall financial management for firms especially those who are capital constrained and more reliant on short term sources of finance [53]. The issue of finance has been identified as an immediate reason why businesses in developing countries fail to start or to progress [54]. An investment group can have various sources of funds, after it has been in business for a while, including debt from financial institutions.

Audits are performed to ascertain the validity and reliability of financial information provided by the managers 
of the reporting entity and an assessment of the entity Internal Control System. Effective and proper accounting system has a profound impact in successful auditing of Small and Medium Enterprises and by extension on the performances of the firms [55]. A positive relationship between the voluntary purchase of business advice and MSE performance and that performance is further enhanced when business advice is purchased jointly with auditing [56].

\section{Methodology}

The study aimed at collecting information from respondents on their opinions regarding the effect of group composition and formalization in financial performance of investment groups. The use of a descriptive survey research design was employed because it gave an in depth investigation of the case that was under study and gave a wide coverage within a short time. It also gave a description of the state of affairs, as it exists [57]. The study targeted the population of registered groups in Nakuru town is 17,945 (Ministry of Labour, Social Security and Services, 2017). A sample of 130 members was selected and 130 groups was selected. The study collected primary data using questionnaires consisting of a series of questions and other prompts for purpose of gathering information. There were two questionnaires. Questionnaire 1 was used to get information on member demographic attributes and the perception of group members on investment groups. Questionnaire 2 was used to get information on group formalization. The set of questions was simple and straightforward, that required straight-forward answers. The data was analysed using regression analysis to establish the effect of group composition and formalization on financial performance. The model is given below.

$$
\mathrm{Y}=\beta_{0}+\beta_{\mathrm{i}} \mathrm{X}_{\mathrm{i}}+\beta_{\mathrm{j}} \mathrm{X}_{\mathrm{j}}+\varepsilon_{\mathrm{i}}
$$

Where:

$\mathrm{Y}=$ Financial Performance was captured as return on investment, measured as net income divided by invested capital.

$\beta_{0}=y$-intercept or constant.

$\beta_{\mathrm{i}}-\beta_{\mathrm{j}}=$ Coefficients beta for each variable.

$\mathrm{Xi}=$ Group Composition (experience, gender, occupation, business training and ethnic diversity)

$\mathrm{X}_{\mathrm{j}}=$ Group Formalization (organizational form, financial management, accounting and auditing, financial reporting and tax returns)

$\varepsilon=$ The error term for performance that cannot be explained by the model.

The significance of this model, which is the overall model, was assessed by comparing the p-value of the F-statistic with the level of significance at an alpha of 0.05 .

\section{Results and Discussion}

The study determined the combine effect of group composition and formalization on financial performance. The study determined the combined effect of group composition and group formalization on group financial performance by regressing the group composition and group performance with financial performance. Group composition consists of experience of members, gender, occupation, business training and ethnic diversity. Group formalization consist of organizational forms, financial management, accounting and auditing, financial reporting and tax returns. Group financial performance consists of returns on investment. A mean was computed from group composition, group formalization and group financial performance and regressed.

Table 1. Model Summary.

\begin{tabular}{lllll}
\hline Model & R & R Square & Adjusted R Square & Std. Error of the Estimate \\
\hline 1 & $941^{\mathrm{a}}$ & 885 & 883 & 1.207 \\
\hline
\end{tabular}

a. Predictors: (Constant), Group Formalization, Group Composition

From Table 1, the results indicate an $\mathrm{R}^{2}$ value of 0.883 . This implies that 88.3 per cent of the total variation in-group financial performance was explained by changes in indicators of group composition.

Table 2. ANOVA ${ }^{a}$.

\begin{tabular}{llllll}
\hline Model & & Sum of Squares & df & Mean Square & F \\
\hline \multirow{2}{*}{1} & Regression & 1122.976 & 2 & 561.488 \\
& Residual & 145.565 & 100 & 1.456 \\
& Total & 1268.541 & 102 & & 385.731 \\
\hline
\end{tabular}

a. Dependent Variable: ROI

b. Predictors: (Constant), Group Formalization, Group Composition

ANOVA was used to estimate significance of regression model, from which an $F$ significance value of $p=0.000$ was established. This indicated that the overall model was significant since the reported probability was less than the conventional probability of 5\% significance level. Thus, using the findings in this study it can be concluded that group composition and group formalization influence the financial performance of investment groups. This was supported by an f statistic of 385.731 . 
Table 3. Effect of Group Composition and Formalization of financial performance.

\begin{tabular}{llllll}
\hline & & & Standardized Coefficients & t & Sig. \\
\cline { 2 - 5 } & B & Std. Error & Beta & .631 & .530 \\
(Constant) & 1.824 & 2.892 & .097 & 2.447 & .016 \\
Group Composition & .209 & .086 & .087 & 22.259 & .000 \\
$\quad$ Group Formalization & .424 & .019 & .886 & & \\
a. Dependent Variable: ROI & & & & \\
\hline
\end{tabular}

$\mathrm{Y}=1.824+0.209 \mathrm{X}_{\mathrm{i}}+0.424 \mathrm{X}_{\mathrm{j}}$

According to the results in Table 3, the coefficient for group composition was $0.209 \quad(\mathrm{p}=0.016)$ which was statistically significant at the 5 per cent level of significance. This suggests that a unit increase in group composition causes 0.209 an increase in financial performance. Also, the coefficient for group formalization was 0.424 which was statistically significant at the 5 per cent level of significance. This suggests that a unit increase in group formalization leads to 0.424 unit increase in group performance.

Business experience according to this study was measured by the number of years a member of an investment group has done investments. As investors do investments over time, they also get older. Cognitive change as a normal process of aging affect some abilities, such as conceptual reasoning, memory, and processing speed, which decline gradually over time. The results of this study corroborates that of [58] who indicated that older investors could accumulate greater knowledge about the fundamental principles of investing, but on the other hand, their declining cognitive abilities would hinder the effective application of those principles. Overall, the adverse effects of aging dominate the positive effects of experience.

The risk propensity of men and women are different. Since women are more risk averse, investment groups of women only tend to invest in low risk but low return avenues leading to poor financial returns. Men are more risk takers therefore groups of men only will tend to invest in high risk high return avenues, exposing them to chances of making great losses hence poor financial performances. Therefore, groups of men and women together are more profitable than single sex groups [59 \& 4].

Investment groups have to know whether they are performing well financially or not. Investments entail record keeping in monetary terms and values. Therefore, investors who have training in accounting and finance will be able to monitor the group's financial progress as well as get timely relevant information from the business environment. Business environment is dynamic, and investors with business training find it easy to cope with emerging improved information technology, management concepts, production techniques and financial systems. These make investors to better identify business opportunities leading to changes in business practices and ultimately higher sales and profits [31]. In addition, costs associated with late returns to revenue collection bodies like KRA will be eliminated.

Formalized investment groups are those that are registered with tax authorities and as such have the obligation to make periodic returns. In order to minimize tax liabilities, these groups must issue tax receipts for every transaction and must keep good records. This will increase efficiency in the operations of the groups leading to improvement in financial performance. In addition, the groups that are registered as limited liability companies must have their books audited by independent external auditors. The auditors normally give the management letters after auditing, highlighting areas of weaknesses in terms of operations. If the management of such groups take keen interest in such weaknesses and take measures for improvement, costs will be minimized and financial performance will improve. The results of this study support a study that there were much higher revenues and profits among firms that were registered for tax [43].

Investment groups that are formalized can access credit for expansion of operations, from financial institutions that can lead to improved financial performance. These institutions evaluate them based on a checklist, which included audited financial statements for the last three years including management accounts and are keener to finance a formal business due to several considerations such as sustained bookkeeping, transparency of businesses processes and access to contractual opportunities [60].

Investment groups that are registered as limited liability companies or limited liability partnerships can have access to government contracts and tenders. This gives them a chance to more transactions that can lead to improved financial performance. The benefits of being formal is the access to public goods and services [61]. This is supported by the results of this study. The majority of unregistered enterprises are not aware of any need to formalize, or of the benefits of participating in different societal institutions [62].

\section{Conclusion}

The findings revealed that group composition components that are experience, gender, occupation, business training and ethnic diversity have significant positive effect on group financial performance. The group formalization components that have significant positive effect on group financial performance were organization form, financial management, accounting, and auditing. Correlation analysis results indicated a moderate positive relationship between group composition and investment group financial performance. Regression results further indicate a significant positive effect. Group heterogeneity affects investment performance in positive ways.

This is because a well-diversified group has members that can bring about a variety in abilities, experiences, knowledge and cultures that may be productive and may lead to innovation and creativity. Secondly, group formalization has 
strong positive significant effect on group financial performance. Formalized investment groups must comply with tax provisions. This forces them to keep good books of accounts and to utilize services of external financial consultants. Formalized investment groups can therefore access credit for expansions because banks normally evaluate them based on a checklist, including audited financial statements for the last three years including management accounts. Lastly, regression results indicate that group composition and group formalization have a positive significant effect on group financial performance. In conclusion, diversified investment groups in terms of experience, gender, occupation, business training and ethnic diversity that are formalized, will experience the best financial performance.

The study recommend that policies should be crafted that encourage gender mainstreaming in investment groups and registration of investment groups with members from different ethnic and occupational backgrounds. Training programs and member education on business skills and proper management practices are paramount in improving the financial performance of these groups.

\section{References}

[1] Patel, C. Y. P., \& Patel, C. C. Y. (2012). A Study Of Investment Perspective of Salaried People (Private Sector). Asia Pacific Journal of Marketing \& Management Review, 1 (2): 126-146

[2] Johnson, J., Thompson, B., \& Polk W. (2002). Starting an Investment club. Texas cooperative extension. Retrieved on 3rd September 2014 from http://www.agrilifebookstore.org/ Starting-an-Investment-Club-p/e-161.htm

[3] Kenya Association of Investment Groups KAIG. (2014). The Chama Handbook $2^{\text {nd }}$ Edition Nairobi

[4] Harrington, B. (2008). Pop finance: Investment groups and the new investor populism. Princeton University Press.

[5] Harrington, B., \& Fine, G. A. (2000). Opening the" black box" Small groups and twenty-first-century sociology. Social Psychology Quarterly, 312-323.

[6] Impio, J. et al. (2009). Merry Go Round: A Study of Informal The Self-help groups (SHGs) in Kenya. Nokia Research Center, Karen, Nairobi, Kenya. Retieved on $4^{\text {th }}$ January 2018 from http://liberationtechnologydcourse.pbworks.com/f/Selfhelp+Groups+Report.pdf

[7] Malkamäki, M., Johnson, S., \& Nino-Zarazua, M. (2009). The role of informal financial groups in extending access in Kenya. Financial Sector Deepening Kenya. Retrieved on $2^{\text {nd }}$ December 2017 from http://www.fsdkenya.org/pdf documents/10-05-

07_Role_of_informal_financial_groups_in_Kenya.pd

[8] Wainaina, T. (2012). Chama to Conglomerate. Reinvesting Your Investment Group. New Delhi, India.

[9] Rae, D., \& Carswell, M. (2000). Using a life-story approach in researching entrepreneurial learning: the development of a conceptual model and its implications in the design of learning experiences. Education and training, 42 (4/5), 220-228.

[10] Nofsinger, J. R., \& Wang, W. (2011). Determinants of start-up firm external financing worldwide. Journal of Banking \& Finance, 35 (9), 2282-2294.

[11] Entine J. (2003). The myth of social investing: a critique of its practice and consequences for corporate social performance research. Organization Environment 16: 352-368.

[12] Barber, B. M., \& Odean, T. (2001). Boys will be boys: Gender, overconfidence, and common stock investment. Quarterly journal of Economics, 261-292.

[13] Bajtelsmit, V. L., and Bernasek, A. (1996). "Why Do Women Invest Differently than Men?" Financial Counseling and Planning. 7, 1- 10.

[14] Sellappan, R., Jamuna, M. S., \& Kavitha, M. T. (2013).Investment attitude of women towards different sources of securities-A factor analysis approach. Global Journal of Management And Business Research, 13 (3): 26-30

[15] Kenya Association of Investment Groups KAIG. (2016). The Chama Handbook $2^{\text {nd }}$ Edition Nairobi

[16] Ou, C., \& Haynes, G. W. (2006). Acquisition of additional equity capital by small firms-findings from the national survey of small business finances. Small Business Economics, 27 (2-3), 157-168.

[17] Jun, S. G., \& Jen, F. C. (2003). Trade-off model of debt maturity structure. Review of Quantitative Finance and Accounting, 20 (1), 5-34.

[18] Menkhoff, L., Schmeling, M., \& Schmidt, U. (2013). Overconfidence, experience, and professionalism: An experimental study. Journal of Economic Behavior \& Organization, 86, 92-101.

[19] Collard, S. \& Breuer, Z. (2009) 'Attitudes towards investment choice and risk within the personal accounts scheme: Report of a qualitative study'. No. 565 Retrieved on $7^{\text {th }}$ November 2017 from http

//www.bristol.ac.uk/geography/research/pfrc/themes /psa/pfrc0902.pdf

[20] Shirokova, G., \& Tsyganova, T. (2010). Gender differences in entrepreneurship: evidence from gem data. Organizations and markets in emerging economies, (1 (1), 120-141.

[21] Mohanta, G., \& Debasish, S. S. (2011). A study on investment preferences among urban investors in Orissa. Prerna Journal of Management thought \& practice, 3 (1), 1-9.

[22] U.S. Department of Labor, Women's Bureau (1994). Handbook on women workers: Trends and issues. Washington, DC: U.S. Government Printing Office.

[23] Singh, J., \& Yadav, P. (2016). A Study on the Factors Influencing Investors Decision in Investing in Equity Shares in Jaipur and Moradabad with Special Reference to Gender. Amity Journal of Finance, 1 (1), 117-130.

[24] King, K. \& McGrath S. (2002) Globalisation, Enterprise and Knowledge: Educational Training and Development, International Review of Education, Vol. 50 (1), 74-76 (3).

[25] Chittithaworn, C., Islam, M. A., Keawchana, T., \& Yusuf, D. H. M. (2011). Factors affecting business success of small \& medium enterprises (SMEs) in Thailand. Asian Social Science, $7(5), 180$. 
[26] Jones, J. (2004). Training and development, and business growth: A study of Australian manufacturing small-medium sized enterprises. Asia Pacific journal of human resources, 42 (1), 96-121.

[27] De Mel, S., McKenzie, D., \& Woodruff, C. (2014). Business training and female enterprise start-up, growth, and dynamics: Experimental evidence from Sri Lanka. Journal of Development Economics, 106, 199-210.

[28] Karlan, D., (2003). Social Capital and Group Banking. Princeton University Research Program in Development Studies Working Paper

[29] Berge, L. I. O., Bjorvatn, K., Juniwaty, K. S., \& Tungodden, B. (2012). Business training in Tanzania: From researchdriven experiment to local implementation. Journal of African economies, 21 (5), 808-827.

[30] Karlan, D., \& Valdivia, M. (2011). Teaching entrepreneurship: Impact of business training on microfinance clients and institutions. Review of Economics and statistics, 93 (2), 510527.

[31] Bjorvatn, K., \& Tungodden, B. (2010). Teaching business in Tanzania: Evaluating participation and performance. Journal of the European Economic Association, 8 (2-3), 561-570

[32] Hassan Al-Tamimi, H. A., \& Anood Bin Kalli, A. (2009). Financial literacy and investment decisions of UAE investors. The Journal of Risk Finance, 10 (5), 500-516.

[33] National Center on Women \& Aging. (1998). Financial challenges for mature women. Waltham, MA: National Center on Women \& Aging, Brandeis University. Retrieved on $12^{\text {th }}$ September 2017 from http://www.heller.brandeis.edu/national/exsum.htm.

[34] Obamuyi, T. M. (2013). Factors influencing investment decisions in capital market: A study of individual investors in Nigeria. Organizations and markets in emerging economies, 4 (7), 141-161.

[35] Velmurugan, G., Selvam, V., \& Nazar, N. A. (2015). An Empirical Analysis On Perception of Investors' Towards Various Investment Avenues. Mediterranean Journal of Social Sciences, 6 (4), 427-435.

[36] Alesina, A., \& Ferrara, E. L. (2005). Ethnic diversity and economic performance. Journal of economic literature, 43 (3), $762-800$.

[37] Putnam, R. D. (2007). E pluribus unum: Diversity and community in the twenty first century the 2006 Johan Skytte Prize Lecture. Scandinavian political studies, 30 (2), 137-174.

[38] Fafchamps, M., 2003. Ethnicity and networks in African trade. Contributions to Economic Analysis \& Policy, Vol. 2 (1), Article 14, Berkeley Electronic Press.

[39] Himbara, D. (1994). The failed Africanization of commerce and industry in Kenya. World Development, 22 (3), 469-482.

[40] Cornell, B., \& Welch, I. (1996). Culture, information, and screening discrimination. Journal of political Economy, 104 (3), 542-571.

[41] La Ferrara, E. (2002). Self - help groups and income generation in the informal settlements of Nairobi. Journal of African Economies, 11 (1), 61-89.

[42] Bigsten, A., Kimuyu, P., \& Lundvall, K. (2000). Informality, ethnicity and productivity: evidence from small manufacturers in Kenya. Department of Economics, Göteborg Univ.

[43] Fajnzylber, P., Maloney, W. F., \& Montes-Rojas, G. V. (2009) Releasing constraints to growth or pushing on a string? Policies and performance of Mexican micro-firms. The Journal of Development Studies, 45: 1027-1047.

[44] McKenzie, D., \& Sakho, Y. S. (2010). Does it pay firms to register for taxes? The impact of formality on firm profitability. Journal of Development Economics, 91 (1), 1524.

[45] Rand, J., \& Torm, N. (2012). The benefits of formalization: Evidence from Vietnamese manufacturing MSEs. World development, 40 (5), 983-998.

[46] Baker, S., \& Krawiec, K. D. (2005). The economics of limited liability: An Empirical study of New York Law Firms. University of Illinois Law Review (1): 107-169

[47] Esch, K. D., \& Spaccarotella, P. L. (1994). Limited Liability Companies as an Alternative Choice of Entity for Farming and Ranching Operations in the State of Nebraska. Creighton $L$. Rev., 28, 19.

[48] Goolsbee, A. (2004). The impact of the corporate income tax: evidence from state organizational form data. Journal of Public Economics, 88 (11), 2283-2299.

[49] Hoe, C. H. (2010). Financial management practices: an indepth study among the CEOs of Small and Medium Enterprises (SMEs). International Review of Business Research Papers, 6 (6), 13-35.

[50] Nandan, R. (2010). Management accounting needs of SMEs and the role of professional accountants: A renewed research agenda. Journal of applied management accounting research, $8(1), 65-78$.

[51] Jarvis, R., Kitching, J., Curran, J. \& Lightfoot, G. A (1996). The Financial Management of Small Firms: An Alternative Perspective, (ACCA research report 490). London: Certified Accountants Educational Trust

[52] Chittenden, F., Poutziouris, P., \& Michaelas, N. (1998). Financial management and working capital practices in UK SMEs. Manchester: Manchester Business School.

[53] Deakins, D., Logan, D., \& Steele, L. (2001). The financial management of the small enterprise. London: Certified Accountants Educational Trust

[54] Abor, J. (2007). Debt policy and performance of SMEs: Evidence from Ghanaian and South African firms. The Journal of Risk Finance, 8 (4), 364-379.

[55] Olasupo, S. F., Sorunke, O. A., \& Olawuyi, L. (2016). Statutory Auditing and Performance of Small and Medium Scale Enterprises in Lagos State, South West Nigeria. International Journal of Academic Research in Business and Social Sciences, 6 (9), 58-67.

[56] Carey, P. J. (2015). External accountants' business advice and SME performance. Pacific Accounting Review, 27 (2), 166-188

[57] Kothari, C. R. (2004). Research Methodology: Methods and Techniques, 2nd Ed. New Age International (P) Ltd., New Delhi.

[58] Korniotis, G. M., \& Kumar, A. (2011). Do older investors make better investment decisions? The Review of Economics and Statistics, 93 (1), 244-265. 
[59] Apesteguia, J., Azmat, G., \& Iriberri, N. (2012). The impact of gender composition on team performance and decision making: Evidence from the field. Management Science, 58 (1) 78-93

[60] Zaman, M., \& Gadenne, D. (2002). A model for best financial and cost accounting practices in SMEs: an exploratory study. Small Enterprise Research, 10 (1), 15-31.

[61] Bennett, R. J., \& Robson, P. J. (1999). The use of external business advice by SMEs in Britain. Entrepreneurship \& Regional Development, 11 (2), 155-180.

[62] Tyrrall, D., Woodward, D., \& Rakhimbekova, A. (2007). The relevance of International Financial Reporting Standards to a developing country: Evidence from Kazakhstan. The international Journal of accounting, 42 (1), 82-110.

[63] Jain, D., \& Mandot, N. (2012). Impact of demographic factors in Investment Decision of Investors in Rajasthan. Journal of Arts, Science \& Commerce, 3 (2), 3.

[64] De Mel, S., McKenzie, D., \& Woodruff, C. (2013). The demand for, and consequences of, formalization among informal firms in Sri Lanka. American Economic Journal: Applied Economics, 5 (2), 122-50.

[65] Berry, T., B. Sweeting, J. Goto \& M. Taylor (2012). Financial management practice amongst SMEs, Working Paper 02/1. Manchester Metropolitan University.

[66] Langowitz, N., \& Minniti, M. (2007). The entrepreneurial propensity of women. Entrepreneurship theory and practice, 31 (3), 341-364.

[67] Verheul, I., Stel, A. V., \& Thurik, R. (2006). Explaining female and male entrepreneurship at the country level. Entrepreneurship and regional development, 18 (2), 151-183.
[68] Levišauskaite, K., \& Kartašova, J. (2013). The impact of individual investor's occupation and investment experience on their decisions to invest. Business Systems \& Economics, 2 (2): 120-129.

[69] Kinyua, J. M. (2005). An empirical investigation of capital structure determinants for small and medium-sized enterprises in Kenya. Unpublished MBA project, University of Nairobi.

[70] Keasey, K., \& Short, H. (1990). The accounting burdens facing small firms: an empirical research note. Accounting and Business Research, 20 (80), 307-313.

[71] Samujh, H., \& Devi, S. S. (2015). Implementing IFRS for SMEs: Challenges for Developing Economies. International Journal of Management and Sustainability, 4 (3), 39-59.

[72] Chrisman, R. D. (2009). LLCs Are the New King of the Hill: An Empirical Study of the Number of New LLCs, Corporations, and LPs Formed in the United States Between 2004-2007 and How LLCs Were Taxed for Tax Years 20022006. Fordham Journal of Corporate \& Financial Law, 15, 459.

[73] Bhushan, P., \& Medury, Y. (2013). Asian Research Consortium. Asian Journal of Research in Business Economics and Management, 3 (12), 147-157.

[74] Olango, E. O. (2014). The Effects of International Financial Reporting Standards Adoption on Smes Performance: A Case Study Mombasa-Central Business District (CBD). Journal of Finance and Accounting, 5 (7), 95-101.

[75] Straub, S. (2005). Informal sector: the credit market channel. Journal of Development Economics, 78 (2), 299-321.

[76] Ishengoma, E., \& Kappel R. (2006). Economic Growth and Poverty: Does Formalization of Informal Enterprises Matter. (Working Paper No. 20). Hamburg. 